\title{
FITOREMEDIASI LOGAM KADMIUM PADA ASAP ROKOK MENGGUNAKAN TANAMAN LIDAH MERTUA JENIS Sansevieria hyacinthoides DAN Sansevieria trifasciata
}

\author{
Jaswiah*, Syamsidar H. Syarifuddin, Iin Novianti \\ Jurusan Kimia UIN Alauddin Makassar \\ *Alamat Korespondensi: syamsidar_hs@yahoo.com
}

\begin{abstract}
Abstrak: Asap rokok mengandung logam kadmium $(\mathrm{Cd})$ yang bila teremisikan ke udara dapat menyebabkan polusi udara. Tanaman lidah mertua jenis Sansevieria hyacinthoides dan Sansevieria trifasciata memiliki stomata tempat masuknya kadmium logam yang kemudian terikat oleh ligan dalam bentuk fitokelatin sehingga dapat digunakan sebagai tanaman fitoremediasi logam Cd. Penelitian ini bertujuan untuk mengetahui berapa konsentrasi maksimum logam $\mathrm{Cd}$ yang terserap oleh tanaman lidah mertua tersebut di atas dari asap rokok jenis non filter dengan variasi waktu kontak dan apakah tanaman tersebut termasuk tanaman hiperakumulator atau tidak terhadap logam Cd. Variasi waktu kontak asap rokok terhadap tanaman adalah 0, 3, 6 dan 9 hari. Penyerapan lidah mertua tanaman $S$. hyacinthoides masing-masing 0,$826 ; 1,314 ; 1.264$ dan $0,876 \mathrm{mg} / \mathrm{kg}$, sedangkan tipe $S$. trifasciata masing-masing 0,$842 ; 0,502 ; 1,386$ dan $1,646 \mathrm{mg} / \mathrm{kg}$. Jadi dapat disimpulkan bahwa tanaman lidah mertua ( $S$. hyacinthoides dan $S$. trifasciata) bukan termasuk tanaman hiperakumolator terhadap logam Cd karena tanaman mampu mengabsorpsi $0,488 \mathrm{mg} / \mathrm{kg}$ dan $0,804 \mathrm{mg} / \mathrm{kg}$ untuk $0.005 \mathrm{~kg}$ sampel.
\end{abstract}

Kata kunci: asap rokok, lidah mertua, logam kadmium, fitoremediasi

\begin{abstract}
Smoking causes air pollution containing Cadmium (Cd) which can be reduced using lidah mertua plant, Sansevieria hyacinthoides and Sansevieria trifasciata. These plants have stomata where Cd metal can enter the plant and then bound to ligand in the form of phytochelatin which make this plant as phytoremediation agent for $\mathrm{Cd}$ metal. The present study was intended to investigate the maximum concentration of $\mathrm{Cd}$ metal absorbed by the plant with varying contact time and whether the plant belongs to Cd hyperaccumulator. The experiment was performed for 9 days and samples were taken at 0, 3, 6 and 9 days time points. The concentration of $C d$ in lidah mertua plant Sansevieria hyacinthoides at 0, 3, 6 and 9 days were 0.826, 1.314, $1,264,0.876 \mathrm{mg} / \mathrm{kg}$, respectively, while for Sansevieria trifasciata were $0.842,0.502,1.386,1.646 \mathrm{mg} / \mathrm{kg}$, respectively. So it can be concluded that lidah mertua plant (Sansevieria hyacinthoides and Sansevieria trifasciata) does not belongs to hyperaccumulator because the plants are able to accumulate $0.488 \mathrm{mg} / \mathrm{kg}$ and $0.804 \mathrm{mg} / \mathrm{kg}$ to $0.005 \mathrm{~kg}$ Cd sample.
\end{abstract}

Keywords: cigarettes smokes, lidah mertua, cadmium, Phytoremediation

\section{PENDAHULUAN}

Pencemaran udara di Indonesia semakin meningkat, sehingga sangat memprihatinkan karena beresiko tinggi pada kesehatan yang akan menyebabkan dampak negatif pada manusia. Udara yang tercemar merupakan polutan yang mengandung bahan-bahan berbahaya. sehingga dapat mencemari lingkungan.

Asap rokok hasil pembakaran merupakan salah satu polutan penyebab pencemaran udara. Asap rokok mengandung bahan kimia yang berbahaya. Sekitar 4.000 bahan kimia diantaranya adalah nikotin, gas karbonmonoksida, nitrogen oksida, hidrogensianida, amonia, akrolein, benzen dan etanol. Adapun bahan tambahan rokok seperti amonia, butana, senyawa kadmium, asam stearat, asam asetat, senyawa arsenat, karbonmonoksida, metana dan metanol. Menurut Padmaningrum (2007), asap rokok mengandung senyawa racun organoklorin seperti: metal-klorida, metilen-klorida, kloroform, trikloroetilen, tetrakloro-etilen dan vinil-klorida.
Rokok juga mengandung logam berat kadmium dalam bentuk kadmium oksida (CdO).

Logam tersebut merupakan unsur yang memiliki tingkat toksisitas yang sangat tinggi dan belum diketahui manfaatnya bagi tubuh, tetapi sangat bermanfaat dalam bidang industri.

Pada proses pembakaran rokok oleh perokok $\mathrm{CdO}$ teremisikan ke udara ambient sehingga dengan banyaknya perokok udara akan terkontaminasi oleh logam Cd.

Salah satu upaya penanggulangan pencemaran udara dilakukan dengan metode fitoremediasi dimana $\mathrm{Cd}$ yang terkandung dalam rokok dibersihkan atau dikurangi menggunakan tanaman yang bersifat hiperkumulator. Tanaman lidah mertua merupakan salah satu tanaman hiperkumulator, tanaman ini mampu menyerap 107 jenis unsur berbahaya. Selain itu tanaman ini juga merupakan tanaman hias yang mampu hidup didaerah yang kering atau tandus dan terdiri atas dua jenis yaitu memiliki daun pendek (sekitar $8 \mathrm{~cm}$ ) dan memiliki daun panjang (sekitar 50$70 \mathrm{~cm})$ 
Udara yang tercemar akan berdampak negatif bagi lingkungan sekelilingnya, sehingga akan merugikan. Logam $\mathrm{Cd}$ yang ditemukan secara bebas di alam dalam bentuk asap rokok, akan berdampak negatif bagi kesehatan baik perokok pasif maupun perokok aktif. Hal tersebut telah dijelaskan oleh Allah SWT mengenai penciptaan manusia sebagai khalifah di muka bumi akan tetapi manusia lebih banyak melakukan kerusakan yang berdampak buruk bagi kelestarian bumi.

Di Indonesia jumlah kematian akibat penyakit dari kebiasaan merokok mencapai 300 ribu pertahun. Hampir 60 persen kematian di Indonesia disebabkan oleh penyakit tidak menular yang disebabkan oleh rokok seperti hipertensi, strok dan penyakit jantung. Perokok di Indonesia, usia di atas 15 tahun pun terus meningkat. Akibatnya pencemaran lingkungan pun semakin meningkat pula. Sehingga diperlukan upaya alternatif untuk mengurangi dampak pencemaran dari asap rokok yang mengandung sekitar 0,13 dan 0,54 ppm logam Cd.

Penelitian tentang penyerapan logam berbahaya yang dilakukan oleh Dewi \& Hapsari (2012) mengenai kajian efektivitas daun puring dan lidah mertua dalam menyerap timbal di udara ambien yang berasal dari kendaraan bermotor. Hasil yang diperoleh dengan metode perlakuan dengan pemaparan tanaman selama 0,12 dan 24 jam di lokasi adalah tanaman puring dan lidah mertua dapat menyerap logam timbal. Berdasarkan hal tersebut, maka dilakukan suatu penelitian fitoremediasi logam Cd pada asap rokok menggunakan dua jenis tanaman hias lidah mertua jenis Sansevieria hyacinthoides dan Sansevieria trifasciata.

\section{BAHAN DAN METODE}

Penelitian dilaksanakan pada bulan Mei sampai Oktober 2015 di Laboratorium Kimia Anorganik dan Laboratorium Riset Jurusan Kimia Fakultas Sains dan Teknologi Universitas Islam Negeri Alauddin Makassar. Alat-alat yang digunakan dalam penelitian ini adalah seperangkat alat Spektrofotometer Serapan Atom (SSA) merk varian, oven, alat-alat gelas, neraca analitik, hot plate, batu didih dan wadah pot bunga.

\section{Bahan}

Bahan-bahan yang digunakan pada penelitian ini adalah alumunium foil, daun lidah mertua ( $S$. hyacinthoides dan S. trifasciata), asam nitrat p.a, asam perklorat p.a, akuabides, larutan standar kadmium $\left(\mathrm{CdNO}_{3}\right)$ dan kertas saring Whatman no. 42 .

\section{Persiapan Tanaman}

Mula-mula tanaman lidah mertua ( $S$. hyacinthoides dan $S$. trifasciata) yang berumur seminggu diisolasi dari udara luar dan ditumbuhkan selama satu bulan kemudian di tempatkan di dalam rumah tanaman yang terbuat dari plastik dengan ukuran $2 \times 2$ meter. Dan masing-masing dinding dibuat lubang untuk sirkulasi udara.

\section{Proses akumulasi oleh tanaman lidah mertua}

Sebelum dilakukan pengasapan secara langsung tanaman lidah mertua terlebih dahulu dilakukan isolasi pada tanaman dan penentuan konsentrasi awal $\mathrm{Cd}$ pada daun sebagai pengontrol dengan metode SSA. Kemudian melakukan pengasapan langsung menggunakan rokok yang telah dirangkai terhadap tanaman lidah mertua.

\section{Pengambilan sampel}

Daun lidah mertua dipetik setiap daun pada masing-masing pot (12 pot jenis $S$. hyacinthoides dan 12 pot jenis $S$. trifasciata), kemudian sampel ditempatkan didalam kantong plastik dan siap untuk dianalisis. Pengambilan sampel dilakukan pada 3, 6, dan 9 hari pemaparan.

\section{Preparasi Sampel dan Pengukuran Kadar Cd}

Sampel yang telah dipetik kemudian dimasukkan ke dalam plastik dan siap untuk dianalisis. Di mana sampel tersebut dipotong kecil-kecil dan dikeringkan kedalam oven dengan suhu $105^{\circ} \mathrm{C}$ selama 2 jam dan ditimbang sebanyak 5 gram sampel (duplo), kemudian didekstruksi basah menggunakan hot plate dengan menambahkan $25 \mathrm{~mL}$ akuabides, $5 \mathrm{~mL}$ asam nitrat p.a dan batu didih sampai menghasilkan gas $\mathrm{NO}_{3}{ }^{-}$yang berwarna kecoklatan. Apabila masih menghasilkan asap berwarna kecoklatan maka sampel tersebut didinginkan dan ditambahkan $1 \mathrm{~mL}$ asam perklorat p.a yang kemudian dipanaskan kembali sampai menghasilkan uap berwarna putih. Setelah itu, sampel didinginkan dan disaring dengan kertas saring Whatman no. 42 dan di masukkan kedalam labu takar $100 \mathrm{~mL}$ kemudian diencerkan dengan akuabides sampai tanda batas. Sampel siap di ukur kadar logam Cd menggunakan SSA dengan lampu hallow cathode lamp $\mathrm{Cd}$ pada panjang gelombang maksimum 228,8 nm.

\section{HASIL DAN PEMBAHASAN}

Absorpsi Logam Cd oleh Tanaman Lidah Mertua

Kandungan $\mathrm{Cd}$ yang terserap oleh daun $S$. hyacinthoides selama 9 hari pengasapan, dapat dilihat pada Tabel 1 .

Tabel 1. Kandungan $\mathrm{Cd}$ yang terserap oleh daun lidah mertua (Sansevieria hyacinthoides)

\begin{tabular}{cccc}
\hline $\begin{array}{c}\text { Variasi } \\
\text { Waktu } \\
(\text { Hari })\end{array}$ & $\begin{array}{c}\text { Konsentrasi } \\
\text { Rata-Rata }\end{array}$ & $\begin{array}{c}\text { Konsentrasi } \\
\mathrm{Cd} \\
(\mathrm{mg} / \mathrm{Kg})\end{array}$ & $\begin{array}{c}\text { Cd } \\
\text { Teradsorpsi } \\
(\mathrm{mg} / \mathrm{Kg})\end{array}$ \\
\hline 0 & 0,0413 & 0,826 & 0 \\
3 & 0,0657 & 1,314 & 0,488 \\
6 & 0,0632 & 1,264 & 0,438 \\
9 & 0,0438 & 0,876 & 0,05 \\
\hline
\end{tabular}




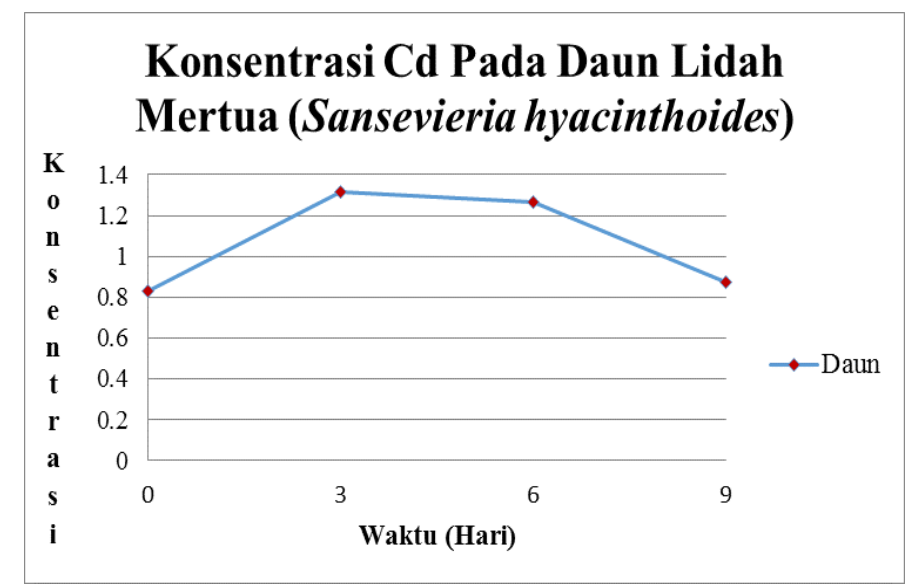

Gambar 1. Grafik penyerapan logam $\mathrm{Cd}$ pada morfologi daun lidah mertua (Sansevieria hyacinthoides)

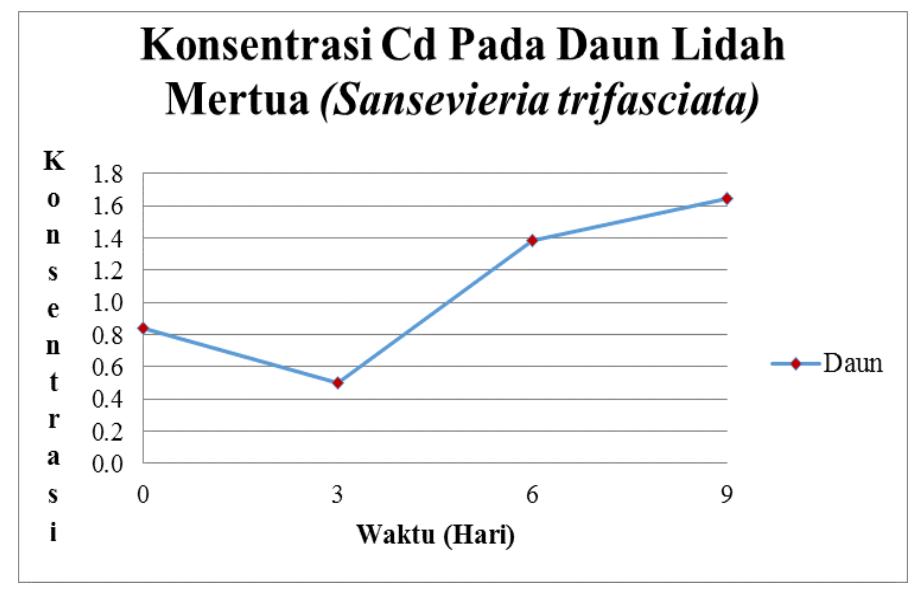

Gambar 2. Grafik penyerapan logam Cd pada morfologi daun lidah mertua (Sansevieria trifasciata)

Berdasarkan hasil penelitian konsentrasi Cd pada daun lidah mertua jenis $S$. hyacinthoides, dapat diketahui bahwa penyerapan $\mathrm{Cd}$ tertinggi terjadi pada hari $\mathrm{ke}-3$ sebesar $1,314 \mathrm{mg} / \mathrm{kg}$ dan mengalami penurunan pada hari ke-9 sebesar $0,876 \mathrm{mg} / \mathrm{kg}$. Kandungan kadmium dapat terlihat pada Gambar 1.

Kandungan $\mathrm{Cd}$ yang terserap oleh daun $S$. trifasciata selama 9 hari pengasapan, dapat dilihat pada Tabel 2.

Tabel 2. Kandungan $\mathrm{Cd}$ yang terserap oleh daun lidah mertua (Sansevieria trifasciata)

\begin{tabular}{cccc}
\hline $\begin{array}{c}\text { Variasi } \\
\text { Waktu } \\
\text { (Hari) }\end{array}$ & $\begin{array}{c}\text { Konsentrasi } \\
\text { Rata-Rata }\end{array}$ & $\begin{array}{c}\text { Konsentrasi } \\
\text { Cd } \\
(\mathrm{mg} / \mathrm{Kg})\end{array}$ & Cd Teradsorpsi \\
\hline 0 & 0,0421 & 0,842 & 0 \\
3 & 0,0251 & 0,502 & $-0,34$ \\
6 & 0,0693 & 1,386 & 0,544 \\
9 & 0,0823 & 1,646 & 0,804 \\
\hline
\end{tabular}

Berdasarkan hasil penelitian konsentrasi Cd pada daun lidah mertua jenis $S$. trifasciata, dapat diketahui bahwa penyerapan Cd tertinggi terjadi pada hari ke- 9 sebesar $1,646 \mathrm{mg} / \mathrm{kg}$ dan mengalami penurunan pada hari ke- 3 sebesar 0,502 mg/kg. Kandungan Cd dapat terlihat pada Gambar 2

\section{Mekanisme penyerapan logam $\mathrm{Cd}$ oleh tanaman Sansevieria hyacinthoides}

Pada penelitian ini digunakan tanaman lidah mertua yang telah di tumbuhkan kembali dalam pot dan di isolasi dan didapatkan hasil penyerapan logam $\mathrm{Cd}$ dengan jenis $S$. hyacinthoides dengan cara pengasapan langsung.

Data yang diperoleh pada penentuan konsentrasi 0 hari (sebelum pengasapan) sebesar $0,826 \mathrm{mg} / \mathrm{kg}$. Hal ini menandakan bahwa tanaman tersebut telah tercemar logam Cd.

Hasil analisis bahwa $\mathrm{Cd}$ yang terabsorpsi tertinggi terjadi pada hari ke-3 dengan konsentrasi sebesar $1,314 \mathrm{mg} / \mathrm{kg}$. Hal ini disebabkan karena 
ukuran partikulat logam Cd lebih kecil dibandingkan ukuran stomata pada daun, sehingga logam Cd masuk kedalam stomata kemudian diikat oleh ligan berupa fitokelatin. Dimana ukuran dari stomata sebesar 10 $\mu \mathrm{m} \times 27 \mu \mathrm{m}$, sedangkan partikulat $\mathrm{Cd}$ sebesar $0,3 \mu \mathrm{m}$ - 0,5 $\mu \mathrm{m}$ sehingga dengan mudahnya $\mathrm{Cd}$ dapat masuk kejaringan daun melalui proses fotosintesis.

Proses fotosintesis merupakan proses pembentukan zat makanan seperti glukosa yang dilakukan oleh tanaman. Proses tersebut berlangsung dengan cara tanaman melepaskan uap air dan mengambil $\mathrm{CO}_{2}$ dan gas lainnya termasuk polutan melalui stomata.

Pada hari ke- 6 dengan konsentrasi sebesar 1,264 $\mathrm{mg} / \mathrm{kg}$ hingga hari ke- 9 dengan konsentrasi sebesar $0,876 \mathrm{mg} / \mathrm{kg}$, logam $\mathrm{Cd}$ yang terabsorbsi mengalami penurunan. Hal ini disebabkan karena daun tersebut mengalami kerusakan fisik dan pembukaan stomata yang tidak sempurna sehingga terjadi penurunan kemampuan tanaman dalam menyerap logam $\mathrm{Cd}$. Bahan pencemar dapat menyebabkan terjadinya kerusakan fisiologi di dalam tanaman khususnya pada daun yaitu rusaknya sel atau disintegrasi, pigmentasi jaringan dan plasmolisis.

Pertambahan umur tanaman akan mengarah pada penurunan kondisi bahkan kematian pada organ. Bagian akhir dari perkembangan sampai hilangnya fungsi dan pengorganisasian disebut penuaan. Penuaan akan dialami semua sel di waktu yang berbeda-beda. Salah satu bagian tanaman yang mengalami penuaan adalah daun, yang disebabkan karena ketersediaan air tanah yang berada pada level rendah sehingga proses fotosintesis akan terhambat mengakibatkan warna daun berubah menjadi kuning, kecoklatan dan akhirnya gugur.

\section{Mekanisme penyerapan logam $\mathrm{Cd}$ oleh tanaman Sansevieria trifasciata}

Pada penelitian ini digunakan tanaman lidah mertua yang telah di tumbuhkan kembali dalam pot dan di isolasi dan didapatkan hasil penyerapan logam Cd (II) dengan jenis $S$. trifasciata dengan cara pengasapan langsung.

Data yang diperoleh pada penentuan konsentrasi 0 hari (sebelum pengasapan) sebesar $0,842 \mathrm{mg} / \mathrm{kg}$. Hal ini menandakan bahwa tanaman tersebut telah tercemar logam $\mathrm{Cd}$ yang diduga berasal dari tanah. Selain itu terdapat pula faktor lain yaitu sebelum tanaman ditumbuhkan kembali terlebih dahulu sudah terkontaminasi oleh logam $\mathrm{Cd}$.

Hasil analisis bahwa $\mathrm{Cd}$ yang terabsorpsi tertinggi terjadi pada hari ke-9 dengan konsentrasi sebesar $1,646 \mathrm{mg} / \mathrm{kg}$, dimana pada hari ke-3 dengan konsentrasi sebesar $0,502 \mathrm{mg} / \mathrm{kg}$ dan hari ke-6 dengan konsentrasi sebesar $1,386 \mathrm{mg} / \mathrm{kg}$ hingga hari ke-9 logam Cd yang terabsorbsi mengalami kenaikan. Hal ini disebabkan karena selama proses pengasapan, stomata dari daun terbuka dengan sempurna. Dimana semakin lama waktu pengasapan, maka kadar $\mathrm{Cd}$ yang diserap tanaman tersebut semakin tinggi. Proses penyerapan $\mathrm{Cd}$ dapat berlangsung dengan baik disebabkan oleh faktor lingkungan seperti cahaya, suhu dan kelembaban. Dimana semakin tinggi intensitas cahaya dapat meningkatkan fotosintesis.

Proses penyerapan logam $\mathrm{Cd}$ pada daun disebabkan adanya ligan berupa fitokelatin yang akan mengikat logam Cd pada daun, dimana ion-ion logam berat $\mathrm{Cd}$ akan berikatan dengan fitokelatin (PC) membentuk ikatan PC-Cd. Fitokelatin merupakan peptida kecil yang mengandung 2 sampai 8 asam amino sistein, sebuah asam glutamat dan sebuah glisin pada ujungnya yang berlawanan. Logam berat $\mathrm{Cd}$ memiliki afinitas yang tinggi terhadap unsur $\mathrm{S}$ yang menyebabkan kadmium $\mathrm{Cd}$ menyerang ikatan belerang (S) dalam enzim sehingga enzim yang bersangkutan menjadi tidak aktif.

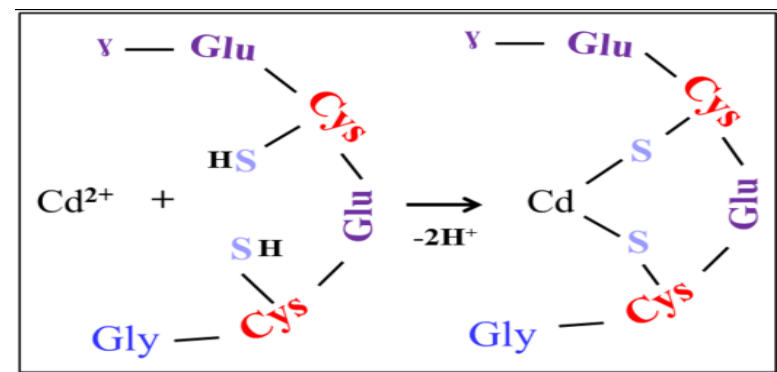

Gambar 3. Proses Terbentuknya Ikatan antara Phytokhelatin dengan $\mathrm{Cd}$

Dibandingkan dengan penelitian sebelumnya mengenai kajian efektivitas daun puring (Codiaeum variegatum) dan lidah mertua ( $S$. trifasciata) dalam menyerap timbal di udara ambien, tanaman $S$. trifasciata mampu menyerap $\mathrm{Pb}$ (II) dengan waktu pemaparan pada (12 dan 24) jam sebesar (0,63 dan 2,14) $\mathrm{mg} / \mathrm{kg}$. Dapat disimpulkan bahwa tanaman tersebut dapat mengurangi polusi udara yang ditempatkan pada ruang terbuka atau udara bebas dengan padatnya polusi udara. Sehingga dilakukan penelitian ini yang berjudul fitoremediasi logam $\mathrm{Cd}$ pada asap rokok menggunakan tanaman lidah mertua (Sansevieria) dalam ruang kedap udara dengan variasi waktu pemaparan 3, 6 dan 9 hari dengan menggunakan 2 jenis Sansevieria yaitu $S$. hyacinthoides yang mengakumulasi logam kadmium (Cd) sebesar $1,314 \mathrm{mg} / \mathrm{kg}$ dan $S$. trifasciata sebesar $1,646 \mathrm{mg} / \mathrm{kg}$.

Berdasarkan hasil penelitian yang dilakukan bahwa kandungan Cd (II) dalam daun lidah mertua jenis $S$. hyacinthoides dan $S$. trifasciata yang diisolasi selama 2 bulan dengan variasi waktu 3, 6 dan 9 hari pengasapan langsung mencapai $0,8 \mathrm{ppm}$ dalam $5 \mathrm{gr}$ sampel kering. Sehingga dapat dikatakan bahwa tanaman tersebut merupakan tanaman akumulator yang dapat mengurangi polusi udara termasuk asap rokok yang mengandung logam $\mathrm{Cd}$. 


\section{KESIMPULAN}

Berdasarkan hasil penelitian maka dapat disimpulkan bahwa konsentrasi maksimum logam $\mathrm{Cd}$ yang diserap oleh tanaman lidah mertua jenis $S$. hyacinthoides sebesar $0,488 \mathrm{mg} / \mathrm{kg}$ pada hari ke- 3 dan jenis $S$. trifasciata sebesar $0,804 \mathrm{mg} / \mathrm{kg}$ pada hari ke- 9.

Tanaman lidah mertua jenis $S$. hyacinthoides dan $S$. trifasciata tidak termasuk tanaman hiperakumulator karena mampu mengakumulasi logam $\mathrm{Cd}$ dengan jenis $S$. hyacinthoides sebesar $0,488 \mathrm{mg} / \mathrm{kg}$ dan jenis $S$. trifasciata sebesar 0,804 $\mathrm{mg} / \mathrm{kg}$ dalam $0,005 \mathrm{~kg}$ sampel.

\section{DAFTAR PUSTAKA}

Dewi, S.Y. \& Hapsari, I. (2012). Kajian efektivitas daun puring (Codiaeum variegatum) dan lidah mertua (Sansevieria trispasciata) dalam menyerap timbal di udara ambien. Jurnal Ilmiah Satya Negara Indonesia. 5(2): 1-7.

Padmaningrum, T.R. 2007 Rokok Mengandung Zat Adiktif yang Berbahaya bagi Kesehatan. Makalah disampaikan pada Kegiatan Pengabdian pada Masyarakat di Aula SMP Budi Mulia, Sendangrejo, Sleman, 4 November 2007. 